\title{
Development of Geotourism in Kutch Region, Gujarat, India: An Innovative Approach
}

\author{
K. Swarna ${ }^{1,2}$, S. K. Biswas ${ }^{3}$, T. Harinarayana ${ }^{1}$ \\ ${ }^{1}$ Gujarat Energy and Research Management Institute, Gujarat, India; ${ }^{2}$ Department of Civil Engineering, Indian Institute of Technol- \\ ogy Kanpur, Kanpur, India; ${ }^{3}$ Earlier at KDMIPE, Dehradun, India. \\ Email: swarna.k24@gmail.com, swarna@iitk.ac.in
}

Received September $18^{\text {th }}, 2013$; revised October $15^{\text {th }}, 2013$; accepted November $12^{\text {th }}, 2013$

Copyright (C) 2013 K. Swarna et al. This is an open access article distributed under the Creative Commons Attribution License, which permits unrestricted use, distribution, and reproduction in any medium, provided the original work is properly cited. In accordance of the Creative Commons Attribution License all Copyrights (c) 2013 are reserved for SCIRP and the owner of the intellectual property K. Swarna et al. All Copyright (C) 2013 are guarded by law and by SCIRP as a guardian.

\begin{abstract}
Geotourism in Kutch has an exemplary potential of being designated as a site for perfect establishment of a National Geopark. The paper is aimed to describe the geological significance of the sites with basic concept of creation of geoparks and promote geotourism. The financial, infrastructural aspects, deliverables to the society are presented primarily focusing on the local economic and sustainable development of Kutch. The need for development of infrastructure for geotourism is urgently required as the rare geological heritage of Kutch region is eroding and being destroyed due to manmade activities.
\end{abstract}

Keywords: Geotourism; Kutch; Geopark; Sustainable

\section{Introduction}

Kutch-the largest district in Gujarat is a place with spectacular geological monuments that has undeniably full potential of being developed as a National Geopark and promote Geotourism in India. It is bounded by the Great Rann on the north and east, Little Rann on the South-East, Gulf of Kutch on the south and the Arabian Sea on the west. It has a warehouse of impressive geological features. The people of Kutch have a rich cultural heritage which is very well acclaimed. In view of all these, the need of the hour is the preservation of the unique geo-heritage of Kutch.

Geotourism plays an important role in displaying the geological features resulted from the processes that began 205 million years ago. The project of establishing the National Geopark in Kutch will be unique and it will be the beginning of geotourism industry in India. State and Central Governments of India are unaware of its rich geological heritage and its economical potential in terms of geotourism. It is high time that the governments should take a note of this and take initiative in protection and preservation of the geological heritage of the district by declaring it as a National Geopark. Soon it can become the member of
Global Geopark Network, resulting in enormous job opportunities, huge revenue collection through geotourism leading to a significant rise in Gross Domestic Product (GDP). This will provide research facilities to geoscientists and promote recreational activities for the general public. Geotourism is an interactive industry; every component needs to go hand in hand. Till now, we do not have this concept. We need cooperation of various communities to create the park. Geological Survey of India initiated action and declared a few locations in India as national geological monuments and fossil-parks. We need to highlight Kutch region and include such geological sites in the tourist map of India.

Ignoring the rare features is a loss to the nation particularly the local community that has large commercial wealth. The present project is aimed to identify the potential geosites in Kutch and to suggest creation of a geopark to conserve the geoheritage. The outstanding geomorphological, stratigraphical, paleontological, sedimenttological and structural heritages of Kutch are of national and international relevance. Without any doubt, creation of geopark will prove to be a remarkable achievement in India's growth in tourism as well as in science and technology sectors. 


\section{Geotourism and Geoparks}

For many years, researchers have been defining geotourism in many ways in accordance with their understanding. The term "Geotourism" is said to be coined first in 1997 by Tourtellot and his wife, Sally [1]. But, the first definition as given below was reported to be given by Thomas Alfred Hose in 1995 who redefined it in 2011 [2] as "The provision of interpretative and service facilities for geosites and geomorphosites and their encompassing topography, together with their associated in-situ and exsitu artefacts, to constituency-build for their conservation by generating appreciation, learning and research by and for current and future generations." However, there are other views and definitions also.

According to National Geographic Society, geotourism is defined as a tourism that sustains or enhances the geographical character of a place-its environment, culture, aesthetics, heritage, and the well-being of its residents [3]. This means that geotourism is a multifaceted sustainable tourism centered on the conservation of geoheritage, appreciating its geological creation through learning and enrichment of the economy.

It is described as multifaceted tourism because it has several aspects with diversified goals underlining the concept. Among other aspects, the conservation is important. To preserve the unique and rare geological features of Kutch, we need to group the sites and declare the entire area as a protected geopark. The agency managing the geopark should aim to provide fair amount of protection measures and collaborate with different departments like Geological Survey, various geoscientific organizations and Institutes, academia, universities and local communities of interests. Preservation of geo-monuments will prove to be a major asset to the country. It will not only meet the needs of the present generation but will take care of the future needs too, hence, covering the sustainability goal. By establishing geoparks, new business ventures and job opportunities will be created for the people from the local community leading to the promotion of local economic development. Through geoparks, people not only from our country but also from overseas may come to visit the geosites for experiencing a fascinating tourism package in Kutch. Geopark will also attempt to organize programs for the propagation of scientific knowledge on geology and environmental concepts to the public. This is to be achieved by providing adequate interpretative facilities that can include proper interpretative panels in geosites, museums, library, and educational tours for children, cartographic tools, visual aids like images and videos, conferences etc. One of its major objectives is also to promote scientific research for which basic laboratory can be set up in geopark office with the help of scientific advisory committee, academic institutions and, thus, covering the learning and research aspects of geotourism as well.

\section{Study Region}

Kutch region of Gujarat exposes many rare features of the Earth that are geologically significant. Such treasured features need to be protected like the wild life, the forests and the environment from human activity. They are the nature's precious gift to us and are natural wealth of India. Any outcrop or a river section exposing a geological feature or a fossil is a rare feature and can be seen only at the place of its occurrence.

The entire Kutch District has a unique landscape with highlands surrounded by vast plains which are extensive mudflats with salt covered white patches (Salinas). Highlands are structural uplifts which expose the rock formations in hilly region. Surrounding plains are structural lows between the uplifts covered by Quaternary and Rann sediments deposited in sea that transgressed into the lowlands and later receded during the structural uplift in recent past. During the marine incursion the uplifts were islands which are seen in the present landscape as uplands scattered over vast plains. These uplands are now described as "islands". There are five such islands namely, Kutch Mainland (the biggest and most populated), Wagad, Pachham, Khadir, Bela and Chorar islands. The last four are collectively called "Island Belt" since they occur in one E-W linear belt.

As seen from the geological map shown in Figure 1, Kutch basin is richly gifted with different deposits and structural features of the geological time scale since 200 million years. Detailed geology and tectonics of the region has been studied by various research workers (e.g. See S. K. Biswas's papers [4-8]). The basin started to form during late Triassic or early Jurassic during breakup of Gondwanaland. Mesozoic, Tertiary and Quaternary sediments were deposited in this basin. There were three phases of rift evolution. Deposition took place during the first phase. The first phase is the synrift phase with normal faulting when Mesozoic sediments were deposited. The next phase was the inversion phase when rifting was aborted as normal faults inverted as reverse faults causing upthrust of fault blocks. The third stage is the postbreak up northward drifting of the Indian plate when strike-slip movement along faults was initiated due to the dominant horizontal stress. From the map, the Mesozoic rocks are seen to be surrounded by Tertiary and Quarternary formations in all the uplifts.

Deccan traps bordering the southern Mainland are the result of the volcanic activity following aborting of the rift during Late Cretaceous. There exist a number of formations like Kaladongar, Goradongar, Jhurio, Jumara, Jhuran and Khadir consisting of sandstone, shale and limestone in Middle to Upper Jurassic, Bhuj formation in Lower Cretaceous, overlain by Deccan Trap lava flows 


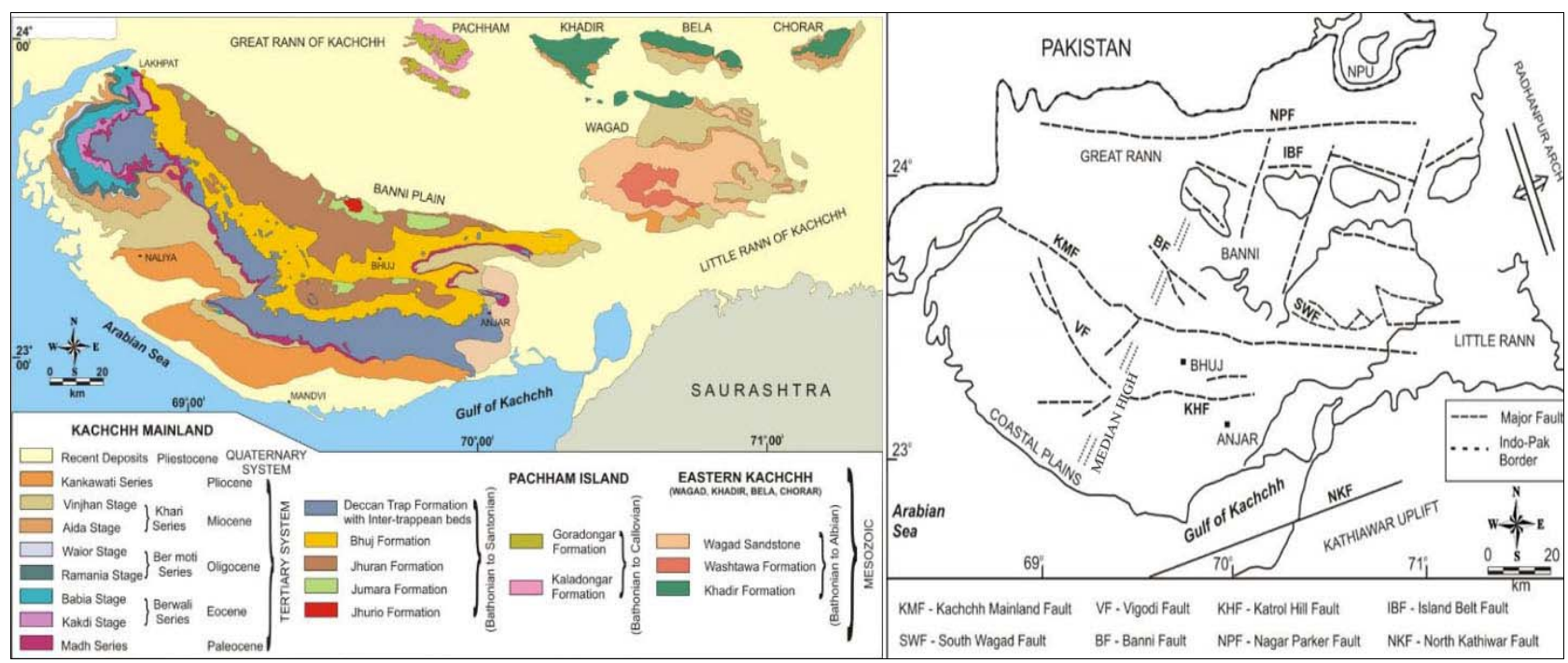

Figure 1. Tectonic and geological map of Kutch showing major faults and stratigraphic units [9].

that erupted in Late Cretaceous to Early Paleocene time when Indian plate was passing over the Reunion hot-spot [8].

The region has unique geological features both on the onland and also on the offshore parts. Series of faultsNagar Parkar, Island Belt, South Wagad, Kutch Mainland and North Kathiawar faults are responsible for the formation of uplifts (horsts), grabens, half-grabens. These features define the uniqueness of onland landscape of Kutch rift basin. The Island belt is broken into four blocks by wrench faults (Pachham, Khadir, Bela and Chorar). Uplifts along the aforementioned faults except the Kathiawar fault resulted in formation of sub-parallel E-W ridges (tilted horsts) while the uplift along the North Kathiawar fault is Saurashtra or Kathiawar horst which marks the southern rift-shoulder of the basin. The basin is bordered by Cambay petroliferous basin in the west and Nagar Parkar-Tharad ridge in the north (northern rift-shoulder). The Precambrian basement is exposed in the Nagar Parkar ridge. The basin extends across the offshore shelf almost upto the present continental slope. There are recent discoveries of petroleum deposits in the offshore part of the basin.

The visitors from the country and overseas can have an insight of all these features formed during the last 200 million years, viz., the sediment deposited in this part of the subcontinent, almost all types of sedimentary structures, the ridges along faults, various types of structural features described in the text books and the impressive occurrence of varieties of fossils etc. Figure 2 shows the rare fossils of dinosaur found in Kutch. Dinosaurs, a group of animals belonging to Dinosauria clan are the giant reptiles that reigned the earth during the Mesozoic period. They first appeared around 230 million years ago in the Triassic period and flourished till $65 \mathrm{My}$. The

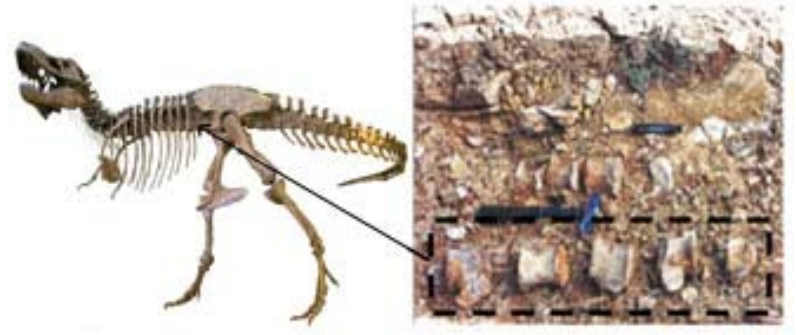

Figure 2. Dinosaur fossils in section in Kuar Bet (near India Bridge), Kutch [10].

Deccan Trap volcanism during Cretaceous-Paleocene period is believed to have led to the extinction of such animal groups.

Palaeochannel (as shown in Figure 3) is an old buried channel representing an ancient river channel that was depositing fluvial sediments cutting through older deposit. Such a rare feature of an age-old spread of river systems can be seen in Kutch in addition to many other sedimentary features. These are unique $3 \mathrm{D}$ models for the students to see actual sedimentary features they read in the books.

Another interesting geological feature is an ammonite and an insect trail as shown in Figure 4. It shows that in the geological past these marine, invertebrate animals were thriving in this basin. Ammonites are the extinct group of free swimming marine invertebrate fauna. They first appeared in Devonian period i.e. around 400 million years ago in Paleozoic era and continued till Cretaceous in Mesozoic era. Kutch is famous for its rich content of the varieties of this fauna.

This piece of awesome geological panorama is due to complex interplay of various processes like change of sea-levels, weather change and movement of the tectonic plates during the last sixty five million years. The area is 


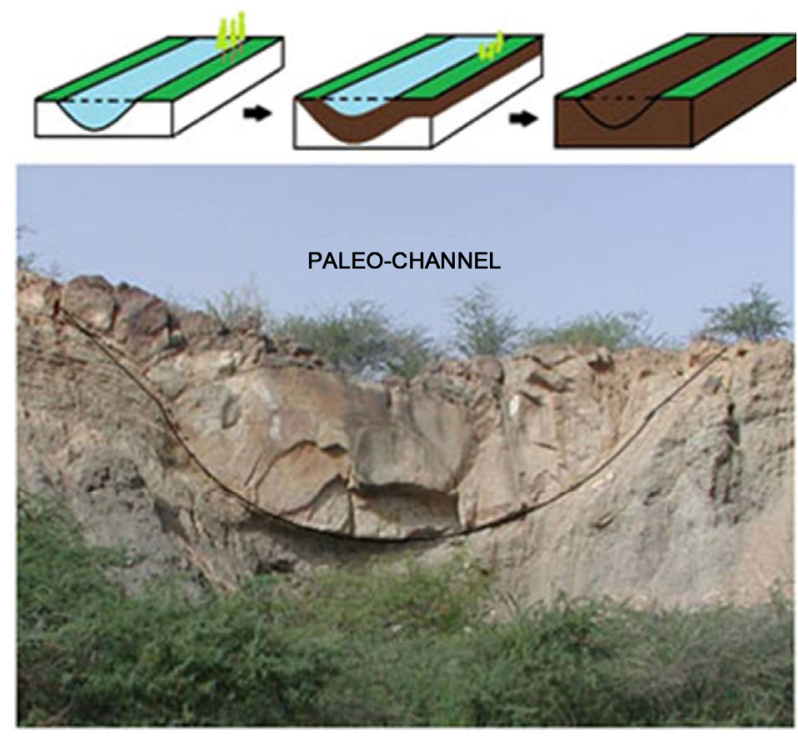

Figure 3. Paleo-channel in Khari Nadi section near crossing of Bhuj-Lodai road: Geologically old system of river channels filled up with sediments; Various stages of formation of paleo-channel is shown. Initially the river is at its original level few million years ago, due to the sediment deposition, the land elevation increases, later the river changes its course due to the infill of sediments and the present day scenario is as shown in the final stage.
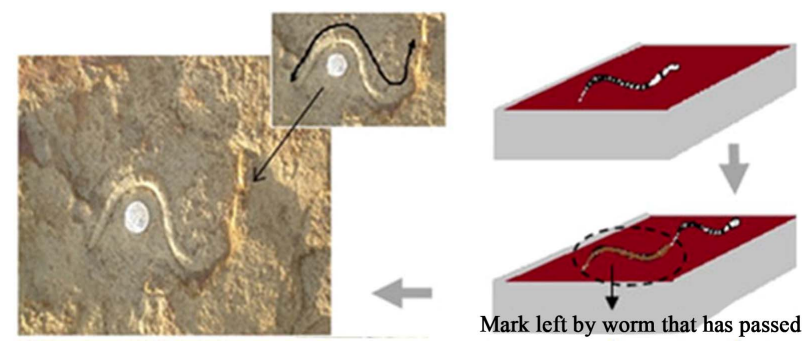

Figure 4. Worm or worm-like trail that has passed million years ago.

seismically very sensitive as it is frequently rocked by severe earthquakes. In short, Kutch landscape with outcrops of richly fossiliferous rocks displays significant paleo-environmental features (Figure 5) like ancient river channels, marine shelf sediments, uplifts, faults and various other geological features. This area is already internationally reputed among the geologists as an important geological province.

Unfortunately, many sites of highly significant geological features will soon cease to exist as major parts of Kutch region has been leased out for mining of limestone and other rocks of economic value. India has no system of regulated mining as in other countries. There are various geosites in this country that do not exist now due to our negligence. The region is like a nature's museum created by God. Once destroyed it cannot be recreated. We need to protect such geoheritage from human activi-

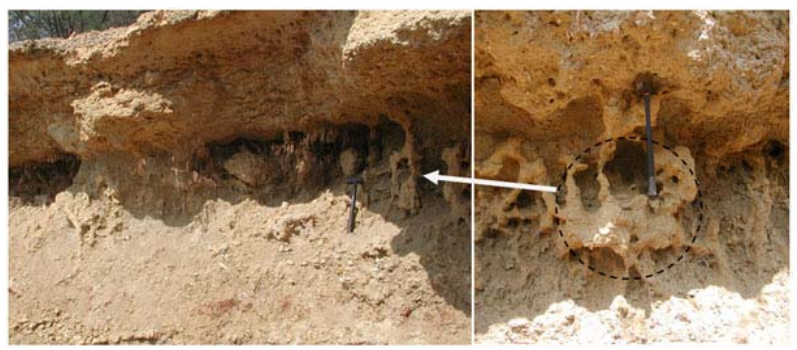

Figure 5. Ichnofossils showing paleo-environmentally significant features in Kankawati river section near Vinjhan: Burrows made by ancient crabs on paleo-shores. Burrows are vertical to the bedding plane and its color is same as that of its host rock with varying cylindrical or elliptical shapes. These features are important to infer the depositional environment of the sediments.

ties or else, we will lose in a short time such a captivating expanse of landscape that could be an ideal place for India's first National Geopark.

\section{Geosites}

Sections of river valleys, road cutting, cliffs, ridges, seacoasts, lakes or manmade trenches which expose important geological features are defined as geosites. In the following paragraphs, a few proposed geosites in Kutch Geopark are described briefly. Generally a geopark is a large area, in which several important geological sections, termed here as "geosites", are present. Depending on the number of such geosites, these are grouped under a few geo-stations for monitoring and better surveillance. In Kutch, 10 geo-stations are suggested from our study under which a total of 50 important geosites have been grouped (listed in Table 1).

A brief discussion of some of these sites is described below.

\subsection{Kaladongar Hill, Pachham Island, Khavda Geo-Station}

Coordinates: $23^{\circ} 55^{\prime} 48.216 " \mathrm{~N}, 69^{\circ} 48^{\prime} 39.9954^{\prime \prime E}$

Age: Middle Jurassic (160 to 178 million years (My))

Babia peak of Kaladongar hills (meaning Black Hill in local language) is the highest peak in Kutch with a height of 462 meters (Figure 6). It is located in Paccham Island, the westernmost island in the Island Belt. This hill occurs along the northern faulted border of the island conspicuously marking the boundary between the rugged hilly terrain and the vast plain of the Great Rann of Kutch. The lower portion of the Kaladongar formation is around 178 million years old. It comprises of alternate bands of sandstone, siltstone and conglomerate while the upper portion consists of sandstone and bands of calcareous sandstones. Younger Goradongar formation overlies the Kaladongar formation showing the change in the rock 
Table 1. List of 50 potential geosites under 10 geopark stations.

\begin{tabular}{|c|c|}
\hline Geo-Stations & List of Potential Geosites \\
\hline Rapar & $\begin{array}{l}\text { GS-1: Rapar-Chitrod road section. } \\
\text { GS-2: Rapar-Lodhrani road section: Maiya Wandh, Desalpur, Fatehgarh sections. } \\
\text { GS-3: Dholavira-Vanjara bet section. } \\
\text { GS-4: Chorar Hill section (at Eval via Santalpur) }\end{array}$ \\
\hline Bhachau & $\begin{array}{l}\text { GS-1: Ahmedabad Highway section, \& Bhachau Fort. } \\
\text { GS-2: Jhuran River \& Jawahar Nagar road section. } \\
\text { GS-3: Dudhai-Devisar section. } \\
\text { GS-4: Kas-Hill-Pur river sections. } \\
\text { GS-5: Chhobari-Manfara-Bharodia section. } \\
\text { GS-6: Adhoi-Kanthkot sections. }\end{array}$ \\
\hline Khavda & $\begin{array}{l}\text { GS-1: Kaladongar Section-Dhrobanu-Dattatraya Temple Road } \\
\text { GS-2: Goradongar Hill sections-Andhou, Juna, Ganiapur, \& KankHill anticlinal hill sections } \\
\text { GS-3: Raimalro Hill section } \\
\text { GS-4: Khavda Nala section } \\
\text { GS-5: Sadhara Dome }\end{array}$ \\
\hline Bhuj & $\begin{array}{l}\text { GS-1: Khari River Section near Rudramata Dam, N of Bhuj City } \\
\text { GS-2: Bhujia Hill. } \\
\text { GS-3: GMDC Cliff section, Ring Road, near Prince Residency Hotel and adjoining road sections. } \\
\text { GS-4: Walakhawas-Fakirwadi section of Katrol Hill range. } \\
\text { GS-5: Bhuj-Dahisar section along Mandvi Road: halipad, Gujarat airport to Mandvi } \\
\text { GS-6: Jhurio Hill Section } \\
\text { GS-7: Habo Hill Section }\end{array}$ \\
\hline Nakhatrana & $\begin{array}{l}\text { GS-1: Vithonia Hill near Vithon } \\
\text { GS-2: Dhinodhar Hill section } \\
\text { GS-3: Mathal-Nara Road section; Kaya Dongar Hill } \\
\text { GS-4: Netra Inter-trappean beds }\end{array}$ \\
\hline Nara & $\begin{array}{l}\text { GS-1: Keera Hill } \\
\text { GS-2: Jumara Hill section }\end{array}$ \\
\hline Dayapar & $\begin{array}{l}\text { GS-1: Lakhapur-Jara section } \\
\text { GS-2: Jaramara Cliff section } \\
\text { GS-3: Amyu (Umia) section } \\
\text { GS-4: Gadhuli-Ghuneri Road section } \\
\text { GS-5: Sahera-Mundhan Hill section } \\
\text { GS-6: Ukra Hill section } \\
\text { GS-7: Akri Nadi section near Dharesi on old Narayan sarovar Road } \\
\text { GS-8: Babia Hill \& adjoining Fulra Nala section on old Narayan Sarovar Road } \\
\text { GS-9: Kapurasi Nadi section } \\
\text { GS-10: Matanumadh river section-Matanumadh cliff \& Lakhpat Road section around Matanumadh }\end{array}$ \\
\hline Naliya & $\begin{array}{l}\text { GS-1: Bhuj-Naliya road section: Dhrubiya Hill, Nana Dongar, Chiasar, Mothala sections } \\
\text { GS-2: Kankawati River Section from Vinjhan to Sandhan }\end{array}$ \\
\hline Lakhpat & GS-1: Lakhpat section \\
\hline Waior & $\begin{array}{l}\text { GS-1: Ramania River Section, W of Goela } \\
\text { GS-2: Khari Nadi section from Laiyari to Chhasra } \\
\text { GS-3: Barkhan River section from Waghapadar to Chheropadi } \\
\text { GS-4: Waior River Section } \\
\text { GS-5: Rakhdi Nadi Section } \\
\text { GS-6: Harudi Cliff Section on Waior-Baranda Road } \\
\text { GS-7: Rato-nala \& Berwali nadi section } \\
\text { GS-8: Ber Moti river section/Maniyara Fort Section } \\
\text { GS-9: Kakdi Nadi section-Nareda Cliff section }\end{array}$ \\
\hline
\end{tabular}

assemblage from sandstones to flaggy limestones and shales. The rock characteristics show that the depositions took place in near shore environment [11].

\subsection{Dhinodhar Hill-A Late Cretaceous Volcano, Nakhtarana Geo-Station}

Coordinates: $23^{\circ} 27^{\prime} 1 " \mathrm{~N}, 69^{\circ} 20^{\prime} 7^{\prime \prime} \mathrm{E}$
Age: Late Cretaceous (69 - 65 My)

It is a volcanic plug formed by hardening of melted rocks from earth's interior (magma) inside an abandoned and eroded volcano. It is located at a beautiful landscape at about 17 kilometers from the town of Nakhtarana towards N-E direction. It came into existence in Late Cretaceous period as an eruptive center of Deccan Trap lavas. It is the second highest peak in Kutch region with a 


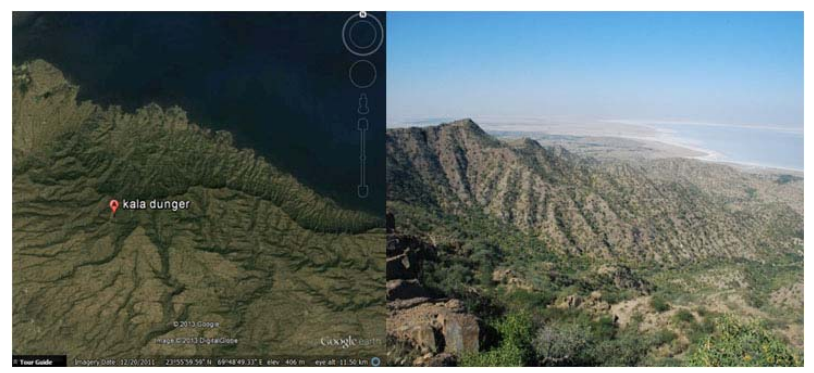

Figure 6. Kala dongar geosite: Location $\left(23^{\circ} 55^{\prime} 59.59 " \mathrm{~N}\right.$, $\left.69^{\circ} 48^{\prime} 49.33^{\prime \prime} \mathrm{E}\right)$ shown in google earth; Kala dongar site, the highest point in Kutch, from where a panoramic view of Great Rann is seen [12]. (Courtesy: Dr. Bhawanisingh Desai, PDPU)

height of 386 meters. The rocks have a striking pattern of columnar jointing in basaltic lava flows (Figure 7).

\subsection{Jumara Hill Section-Rich in Ammonite Assemblage, Nara Geo-Station}

Coordinates: $23^{\circ} 42^{\prime} \mathrm{N}, 69^{\circ} 4^{\prime} \mathrm{E}$

Age: Middle to Upper Jurassic (150 to 166 My)

The Jurassic stratigraphy is prominently exposed in Jumara dome (Figure 8) located in the western part of Northern E-W anticlinal ridge in Kutch mainland. Jhurio, Jumara and Jhuran formations are exposed in the dome. This geosite is the type section of the Jumara Formation (Mid-Jurassic) which is well exposed here with its rich fossil assemblage at the core of the dome. Entire $300 \mathrm{~m}$ thickness of this formation is exposed here. This site is a natural fossil museum with ammonites, bivalves, and corals strewn all over the place. One can also find rare Jurassic foraminifera in these rocks [15]. It comprises shales and fossiliferous oolitic limestones (Dhosa Oolite member) near the top. Oolites are tiny spherical grains with concentric layers. It is overlain by the Jhuran formation of Upper Jurassic age comprising sandstones and shales. This geosite in a barren land bordering the Banni plain is truly a fascinating spot for geo-tourists.

\subsection{Jara Dome: Lakhapur-Jara Section, Dayapur Geo-Station}

Coordinates: Between $23^{\circ} 43^{\prime} \mathrm{N}$ to $23^{\circ} 45^{\prime} \mathrm{N}$ and $68^{\circ} 57^{\prime} \mathrm{E}$ to $69^{\circ} 00^{\prime} \mathrm{E}$

Age: Middle to Upper Jurassic (150 - 166 My)

This site is rich in geological heritage and uncovers the features of Jara Dome structure (Figure 9). It is located at the outskirts of N-W of Kutch Mainland adjacent to the Banni plain, about 20 kilometers from Dayapar Geopark station. The dome is around 3 kilometers in diameter and shows a prominent quaquaversal dipping. Many fossil assemblages of belemnites and ammonites have been recorded in this area. The dome comprises of Jumara formations of thick beds of shale overlain by sandstone-shale of Jhuran formation. Dhosa Oolite beds

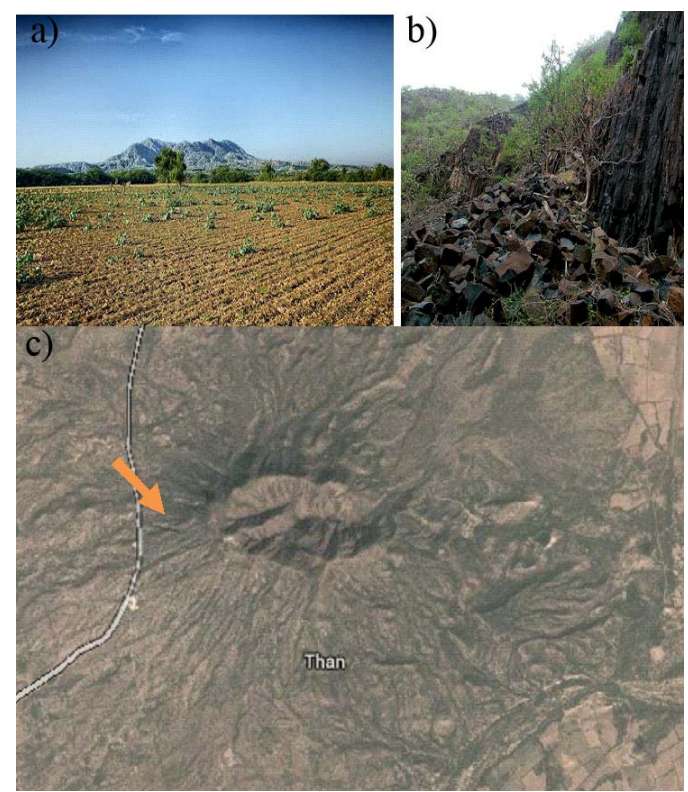

Figure 7. a) Dhinodhar Hill Geosite: Volcanic plug and rock patterns of columnar joints. For a closer view at the rock patterns, visit the page-http://www.dinodia.com/photos/A52263452.jpg; b) Dhinodhar Hill volcano one of sources of Deccan trap lava flows; c) Shield Volcano Crater in Deccan trap; Volcano: Dhinodhar hill, one of the eruptive centers of Deccan Trap, Kutch [13].
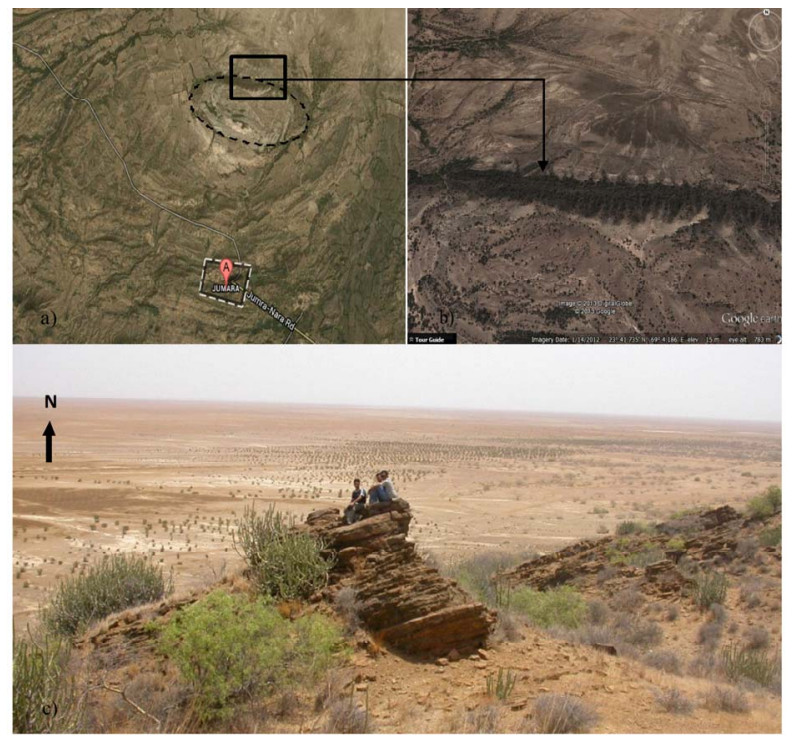

Figure 8. Jumara $\left(23^{\circ} 41^{\prime} \mathrm{N}, 69^{\circ} 4 ' \mathrm{E}\right)$ : a) Location of dome near Jumara village; b) Photo is taken at the location of Jumara dome north-flank viewing north over Banni mudflat [14]. c) Photo of the Jumara dome site. (Courtesy: Dr. Bhawanisingh Desai, PDPU)

in the lower shale beds exposed at the core of the Jara dome marks the boundary between Jumara and Jhuran formations. The dome is marked by various faults and occurrence of doleritic dyke in the vicinity of the faults as shown on a map (Figure 9(b)) [17]. 


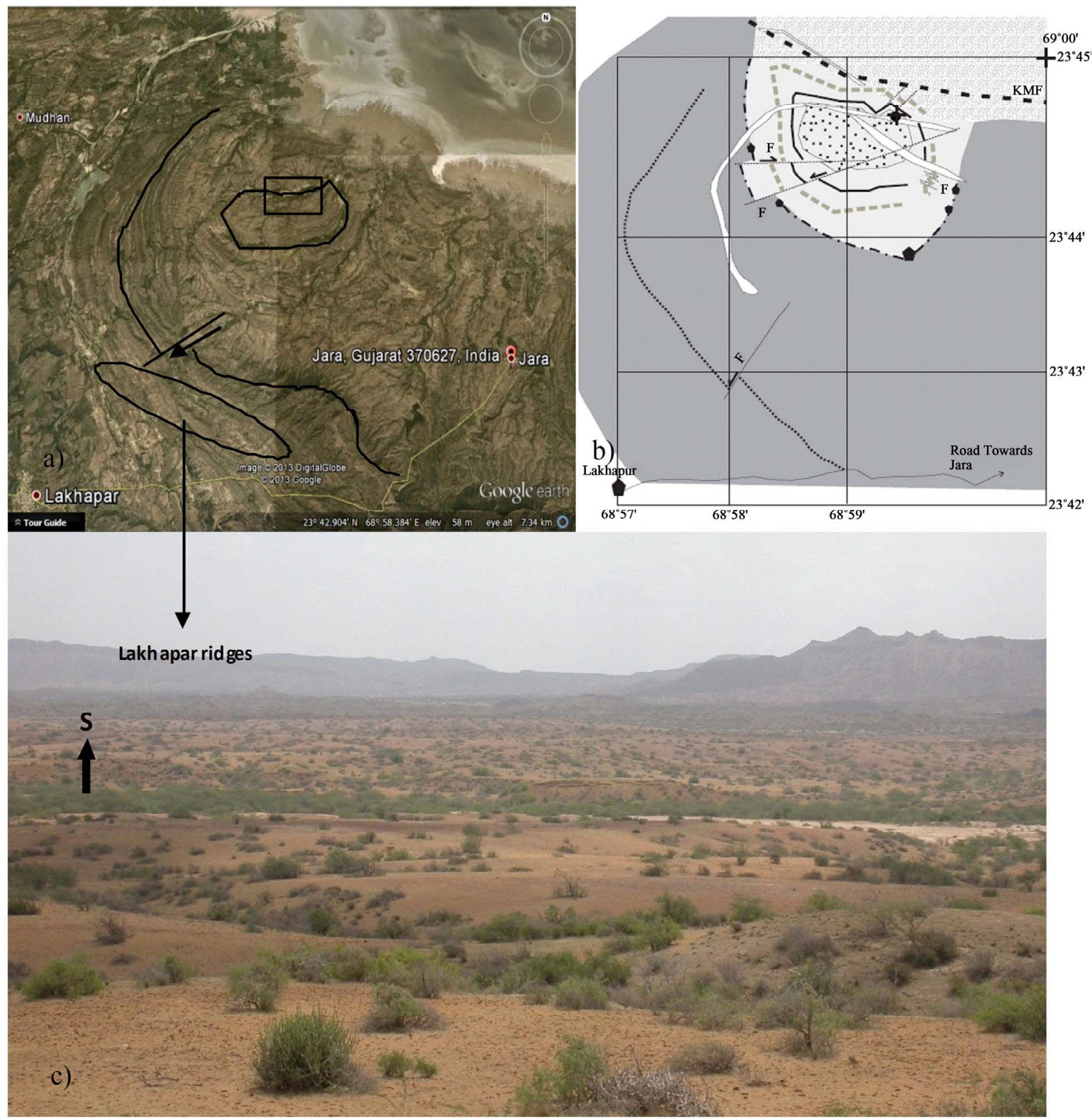

Figure 9. Jara $\left(23^{\circ} 44^{\prime} \mathrm{N}, 68^{\circ} 59^{\prime} \mathrm{E}\right)$ : a) Location of Jara dome along the Lakhapar-Jara road as marked in the figure; b) The figure shows the jumara sediments at the core, doleritic dyke cutting through the hills, dhoosa oolite bed and strike-slip faults; c) Photo is taken at the marked location of Jara site viewing the Lakhapar ridges towards the south of Jara [16]. (Courtesy: Dr. Bhawanisingh Desai, PDPU)

\subsection{Ukra Hill Section-Early Cretaceous Marine Transgression within Deltaic Deposits, Dayapur Geo-Station}

Coordinates: Between $23^{\circ} 47^{\prime} 06^{\prime \prime} \mathrm{N}$ and $23^{\circ} 45^{\prime} 30 " \mathrm{~N}$ and $68^{\circ} 50^{\prime} 43^{\prime \prime} \mathrm{E}$ and $68^{\circ} 51^{\prime} 25^{\prime \prime} \mathrm{E}$

Age: Early Cretaceous (112 to $124 \mathrm{My}$ )

Ukra hill geosite (Figure 10) exposes the marine beds of the middle member of Bhuj formation which comprises mainly sandstones deposited as Early Cretaceous
Delta. It is the youngest Mesozoic formation exposed extensively across Kutch mainland from Ghuneri in the west to Bhachau in the east overlying marine Jurassic formations. The Ukra marine beds are exposed in Ukra Hill, South of Ghuneri in Western Kutch near the western corner of the Mainland. The Ukra beds are green glauconitic shales with fossiliferous calcareous and ferruginous sandstone bands [19]. It contains ammonites dated as Aptian. Pieces of fossilwoods and bivalve Tri- 


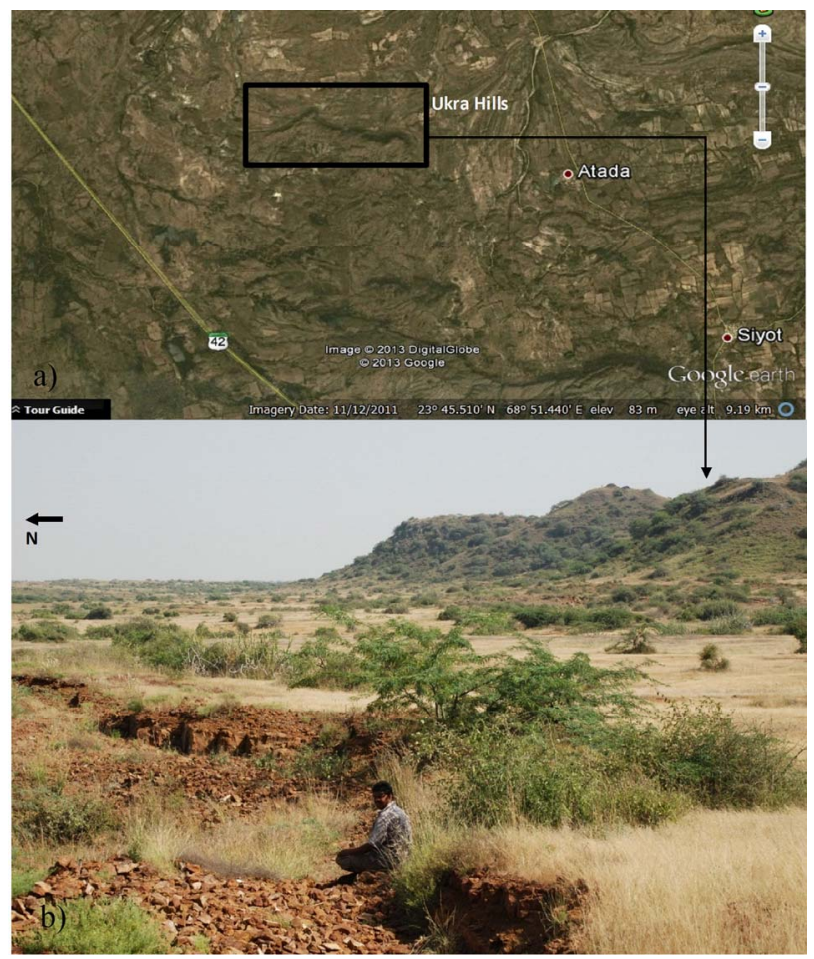

Figure 10. Ukra Hill site $\left(23^{\circ} 45^{\prime} \mathrm{N}, 68^{\circ} 51^{\prime} \mathrm{E}\right)$ : a) Location of Ukra hills in Google Earth; b) Photo shows the ferruginous sandstone base of the Ukra beds near hill [18]. (Courtesy: Dr. Bhawanisingh Desai, PDPU)

gonia are also common. The Ukra member's green shale and marl beds at the base of the hill are distinctive between the yellowish grey and light brown sandstones of Ghuneri and upper members. The Ukra sequence is about 30 meters thick. It represents a short marine transgressive phase during the Lower cretaceous deltaic sedimentation. This is one of the spectacular sites in Kutch.

\subsection{Lakhpat-Tertiary Limestone Formations, Dayapar Geo-Station}

Coordinates: $23^{\circ} 49^{\prime} 52.57 " \mathrm{~N}, 68^{\circ} 46^{\prime} 30.43^{\prime \prime} \mathrm{E}$

Age: Middle Eocene (38 to $50 \mathrm{My}$ )

Lakhpat geosite (Figure 11) is a large area of wellexposed Middle Eocene Fulra limestone formation. The limestones are packed with varieties of fossils of Nummulites species. Nummulites are one of the important micro-fauna in the marine early Tertiary seas across the globe. This limestone belt extends from Lakhpat at the Western end to Vinjhan at the south-central region of the Mainland. The Nummulites are basically very unique fossils and can easily be recognized because of its coin shaped structure. Limestones are packed with these fossils and hence called Nummulitic Limestone. More than thirty species of benthic and planktonic foraminifera were identified from this Middle Eocene sequence [20]. Fossils of crab species belonging to Paleogene (23 to 65
My) and Neogene (3.4 to $23 \mathrm{My}$ ) times are common in these limestone [21]. Besides fossil forams, fossil Bryozoa [22] and algae, varieties of gastropods, lamellibranches and echinoids are also common as well as bones of fossil whales and crocodiles.

Almost the entire limestone belt has been leased out to 5 Cement factories for mining. This will lead to the excavation and total destruction of this precious limestone deposit, a rich geological heritage of the country. Unless immediate actions are taken we will lose this unique natural heritage soon. This beautiful white limestone form high cliffs along the rivers all along its outcrop bordering southern Kutch Mainland. This beautiful landscape will be lost soon unless the local authorities take immediate action to restrict mining operation. We cannot afford to lose such scenic beauty as well most significant geo-heritage that attracts large number of paleontologists for research from all over the world.

\subsection{Ber Moti River Section-Maniyara Fort Geo-Station}

Coordinates: Between $23^{\circ} 25^{\prime} 00^{\prime \prime} \mathrm{N}$ to $23^{\circ} 28^{\prime} 05^{\prime \prime} \mathrm{N}$ and $68^{\circ} 35^{\prime} 00^{\prime \prime} \mathrm{E}$ to $68^{\circ} 37^{\prime} 00^{\prime \prime} \mathrm{E}$

Age: Oligocene (23 - $35 \mathrm{My}$ )

This geosite is located 15 kilometers from Waior, a village in the southwestern Kutch. A section of Maniyara Fort formation is well-exposed along Ber Moti stream upto Maniyara Fort cliff. A distinctive ochre to yellow colored limestone contatining foraminifera is seen with a basal greenish glauconitic siltstone. Bermoti member is about 10 meters thick and is well-developed in the stream southeast of Bermoti and also north-northeast of Waior and on the top of Maniyara Fort Hill. It consists of rusty brown, crumbly glauconitic argillaceous sandstone in the lower part, and coralline limestone with coral bioherms (small coral reefs) in the upper part [25]. The disconformable contact between Middle Eocene Fulra Limestone and Basal glauconitic beds of the Oligocene Maniyara Fort formation is very well exposed in Ber Moti river section and Maniyara Fort cliff on its left bank.

\section{Geo-Corridor}

For an effective Geopark implementation, a proper infrastructural planning is required. Kutch region has the biggest advantage of excellent logistic support with net work of good roads. It has also the advantage of crosscountry driving over the semi-arid region with scanty vegetation. Almost all the geosites are accessible and well exposed. It is only necessary to improve the foottracks as motorable roads in some cases. Several traverses should be planned along selected routes to cover the geosites. Tourists could be given the opportunity to select routes according to their choice, particularly the tourist geoscientists and researchers. Some impressive 


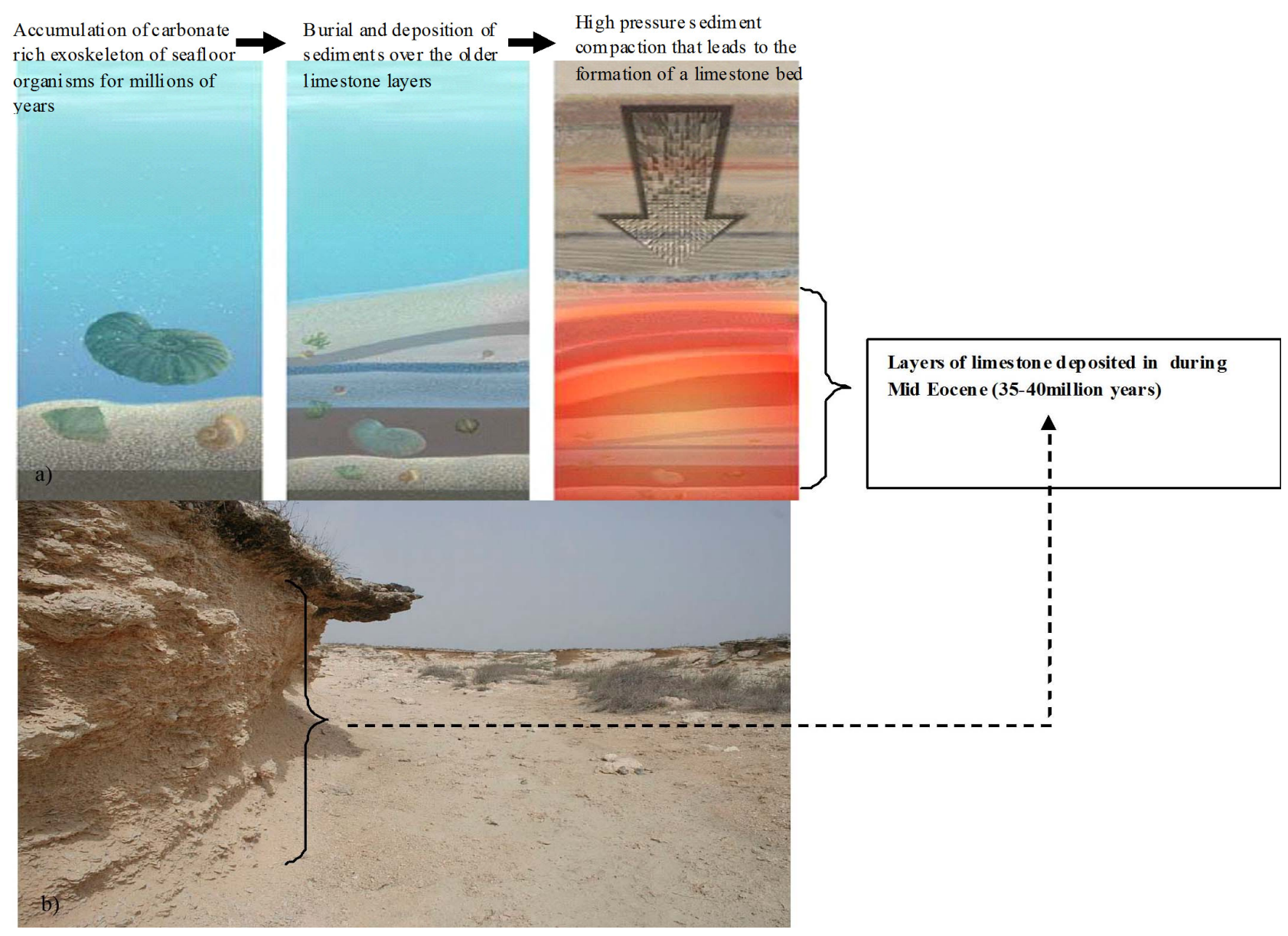

Figure 11. Lakhpat geosite (Fulra Nala section): a) The figure shows processes involved in the formation of limestone deposit by precipitation of $\mathrm{CaCO}_{3}$ with fossils-Burial takes place as sediments accumulate and the older deposited sediments compact. Due to physical and chemical changes, these sediments lithify into rock beds [23]; b) Limestone formations of Lakhpat geosite [24].

sites with scenic beauty and common interest could be specially listed for common visitors along a few chosen traverses.

For exposing distinct anticlinal, synclinal and fault features in the hill ranges, geo-corridors across the hills could be planned as proposed here. Such corridors can be created by cutting pathway across the hills around 5 meters deep from the ground level and construct motorable roads to enable the tourists to travel. For example, cutting through the Sadara dome geosite of Khavda Geo-station will expose different older to younger members with varying dip angle as shown in the conceptual diagram (Figure 12). Geo-corridors may portray the succession of rock formations like Kaladongar and Goradongar formations as one goes from north to southeast of Khavda.

\section{Financial Aspects}

In any project, effective cost management plays a crucial role. For a secure geopark planning, essential resources were figured out and its approximate costs were esti- mated and a tentative project budget plan (Table 2) has been laid out that may help the government agencies. The implementing authorities for funding arrangements can be public as well as private establishments keeping in mind the economic viability and lined up with the overall common objective of sustainable and economic development. The private sector may contribute its share of investment in addition to the functional expertness. The entire project cost will include the shares of eligible stakeholders. Investment in Geoparks will definitely prove to be profitable as seen from the revenue collections of geoparks in overseas [27] and also be productive for scientific research as well as enhancement of geological knowledge and helps to bridge the gap between general public and geology.

In Kutch following essential infrastructures are needed to be established: A building for Geopark \& Tour Headquarters at the district capital Bhuj, the building should be designed to house the office, a library, museum, a laboratory equipped with instruments for study of rock 


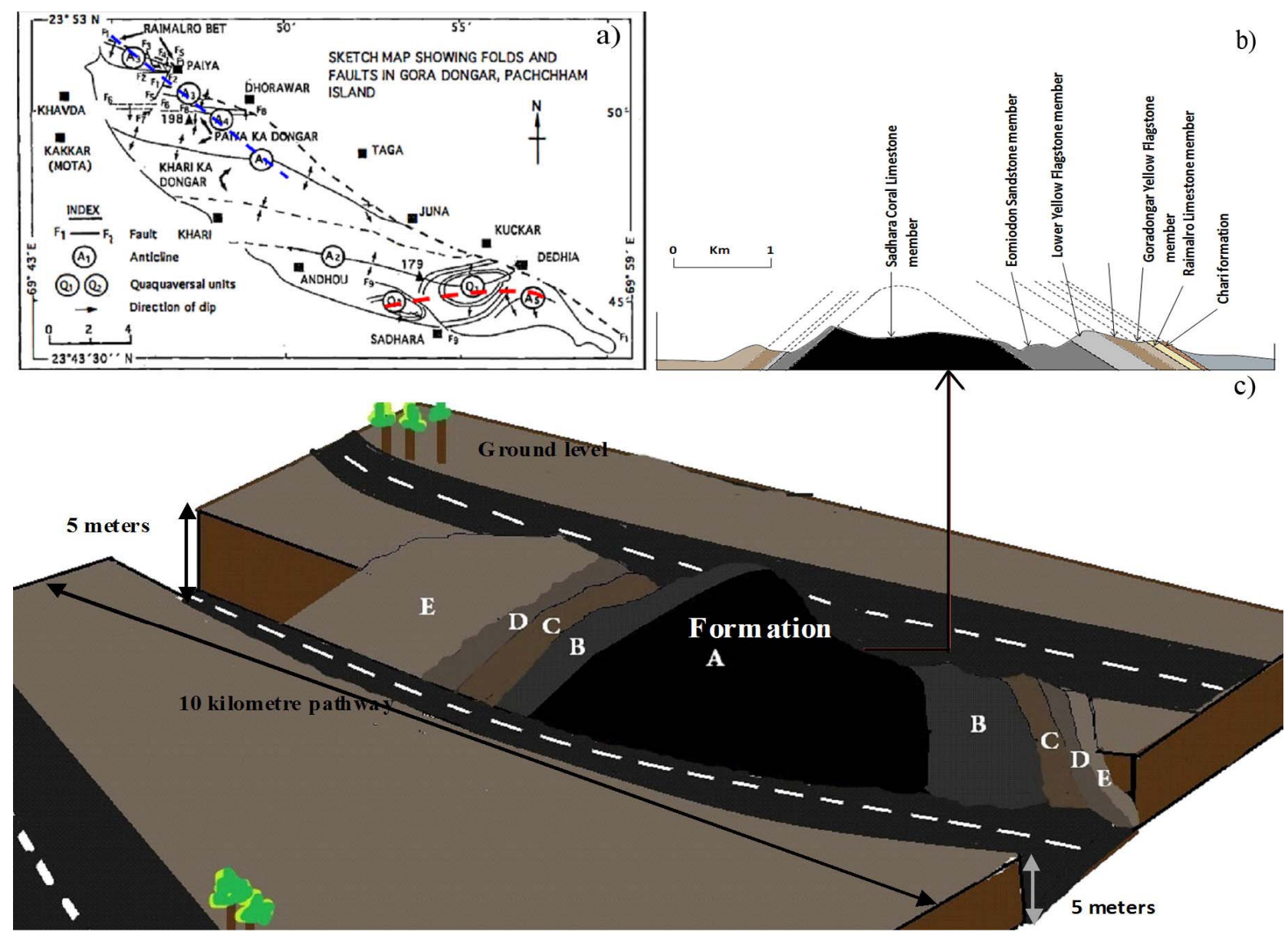

Figure 12. Concept diagram. a) Geo-corridor (pathway marked blue and red) cutting the Anticline structure and quaquaversal dipping beds of Dome; b) A section of Sadara dome, Khavda geopark; c) Red marked geo-corridor of 10 kilometers across Sadara Dome exposing the beds of various formations [26].

samples, office building at each geostation and a training centre to train selected local people as effective tour guides. It is also necessary to build a Guest House mainly for the students, researchers and scientists. It is necessary to print catalogues for information regarding geostations and geosites and attractive pamphlets for advertisement purposes.

\section{Discussion and Conclusion}

The Kutch region of Gujarat can be very effective in initiating Geotourism Industry in India. It will be unique experience in India in tourism sector. Gujarat tourism has already received 3 national tourism awards-best tourism film, innovative use of information and technology and best state for comprehensive development of tourism in the country and it has also been rated among the world's 10 unsung places by "Lonely Planet" magazine. Hence, we are now in level to captivate the interests of visitors from overseas too. Gujarat has insignificant contribution of foreign tourist visits according to the tourism statistics of 2011 provided by the Ministry of Tourism, Govern- ment of India [28]. The creation of geopark development will attract not only the domestic visitors but also help to raise the number of visitors from abroad and pave a way to increase the revenue to the Government.

As of now the political scenario is ripe to develop tourism in Gujarat. For example, the Chief Minister of Gujarat aspires to develop tourism to its full potential and wants to maximize the employment and GDP [29].

The tourism budget has now amounted to Rs. 500 crore from Rs. 30 crore in 2005-2006. In the last year Gujarat got over 22 million tourists and witnessed a tourism growth rate of over $16 \%$, which is the double of the national tourism growth rate. Additionally, geotourism play a prominent role to add a significant number to this growth rate. Firstly considering the geotourists, they will have to pay an entrance fee and purchase information documents, particularly the geologist tourists coming for research and related field studies. They have to select geosites to be visited and studied and pay special fees accordingly and obtain a license for field work and carrying out various studies by breaking rocks, digging 
holes and shallow trenches etc. Also, they will have to pay for information documents like maps, sections, litho logs etc. Lastly, they have to pay for collected samples which they want to take away with them for further lab studies. Moreover, the local men should be trained as tour guides and posted at the geo-stations by the tourist agencies. This will create job opportunities for local villagers. The final deliverables of geotourism include large increase in the job opportunities for the local communities as well as people from different fields and enormous collection of revenue. It will definitely contribute to the growth in GDP as seen recently in China where the geotourism industry has established a Jinhu geopark which has led to $13.5 \%$ increase in its GDP employing 2800 masses and collecting revenue of 202 million Yuan [27].

According to India's 12th five year plan, it has been emphasized that there is a need to employ "pro-poor and sustainable tourism" which will definitely promote the local economy and will also benefit the non-cash lively hood of the locals by enhancing their accessibility to various services and infrastructure. According to the ministry of tourism, more focus should be on clusters of rural tourism and tourism parks. Favorably, geotourism primarily aims at the aforementioned matters. This aids in achieving the goals of the 12th five year plan. One of the strategies of the recent five year plan is to shift from stand alone approach to a cluster approach which is basically the geopark creation can do. The plan also aims at identifying a tourism circuit and geotourism Corporation can help the government in identifying a circuit of geological monuments in Kutch [30].

The potential of Kutch's geoheritage can be turned into a reality with the development of infrastructure. This is one of the primary requirements for the success of the project. Fostering of geosites has to be done keeping in mind the provision of all the basic facilities to the geotourists. The accessibility to such sites should be worked out with logistics management. Needless to say that geopark implementing agency is to closely work with socioeconomists and scientists, geological survey of India, officers of governmental bodies, various partners and local communities of interests. To uphold the fun element, proper management is required that it will take care of recreational activities like scenic flight ride, conducting handicraft workshops that can lead to huge involvement of local handicraftsmen. It also helps in creation of jobs and flow of income, establishing geo-plaza for shopping as well or geo-sports. An effective geo-tour planning is desired for exploring the geopark circuits alongside providing scientific and geological knowledge at the interpretative center at the headquarter in Bhuj. A route map for geo-tour to Nakhatrana geopark comprising of $\mathbf{4}$ geosites is suggested in Figure $\mathbf{1 3}$ starting from

Table 2. Budget estimation of 50 geosites of geopark project in Kutch.

\begin{tabular}{|c|c|c|c|c|}
\hline Budget Component & Cost (in Crores) & Possible Implementing Agency & Mode of Funding & Existing Schemes \\
\hline Landscaping/Beautification of 50 Geosites & $0.50 \times 50$ & $\begin{array}{l}\text { Tourism Corporation of } \\
\text { India/Gujarat }\end{array}$ & $\begin{array}{c}\text { Public Private } \\
\text { Partnership (PPP) }\end{array}$ & $\begin{array}{l}\text { Product Infrastructure } \\
\text { Development for Destination } \\
\text { \& Circuits (PIDDC) }\end{array}$ \\
\hline Information and Directional Panels & $0.02 \times 50$ & $\begin{array}{l}\text { Tourism Corporation of } \\
\text { India/Gujarat }\end{array}$ & Public & PIDDC \\
\hline Public Convenience & $0.30 \times 50$ & $\begin{array}{l}\text { Tourism Corporation of } \\
\text { India/Gujarat }\end{array}$ & PPP & $\begin{array}{c}\text { Urban Infrastructure } \\
\text { Development Scheme for } \\
\text { Small and Medium Towns } \\
\text { (UIDSSMT) }\end{array}$ \\
\hline Pathway Amenities & $1.50 \times 50$ & $\begin{array}{c}\text { National Highway Authority of } \\
\text { India (NHAI)/Public Works } \\
\text { Department (PWD) }\end{array}$ & PPP & UIDDSMT \\
\hline Benches and Shades & $0.10 \times 50$ & $\begin{array}{l}\text { Tourism Corporation } \\
\text { of India/Gujarat }\end{array}$ & Public & PIDDC \\
\hline $\begin{array}{l}\text { Geo-Hotels for Economic } \\
\text { Accommodation and Geo-Restaurants }\end{array}$ & $8 \times 10$ & $\begin{array}{l}\text { Tourism Corporation } \\
\text { of India/Gujarat }\end{array}$ & PPP & $\begin{array}{l}\text { PIDCC/Central Financial } \\
\text { Assistance (CFA) }\end{array}$ \\
\hline $\begin{array}{c}\text { Retail Complexes-Telephone } \\
\text { Services/ATMs/ }\end{array}$ & $0.21 \times 10$ & $\begin{array}{l}\text { Tourism Corporation } \\
\text { of India/Gujarat }\end{array}$ & PPP & PIDDC \\
\hline $\begin{array}{c}\text { Development of Facilities for } \\
\text { Festival/Exhibition/Thematic Events }\end{array}$ & $0.3 \times 10$ & $\begin{array}{l}\text { Tourism Corporation } \\
\text { of India/Gujarat }\end{array}$ & PPP & - \\
\hline $\begin{array}{c}\text { Development of Facilities for Recreational } \\
\text { Activities_-Geo-Sports/Workshops/ } \\
\text { Ropeway Ride etc. }\end{array}$ & 5 & & PPP & UIDDSMT \\
\hline Administrative Headquarter Services & 2 & PWD & PPP & UIDDSMT \\
\hline Monitoring & 0.6 & $\begin{array}{l}\text { Tourism Corporation } \\
\text { of India/Gujarat }\end{array}$ & Public & PIDDC \\
\hline Others & 3 & $\begin{array}{l}\text { Tourism Corporation of } \\
\text { India/Gujarat/PWD/NHAI }\end{array}$ & Public/ PPP & - \\
\hline TOTAL & 216.7 Crores & & & \\
\hline
\end{tabular}



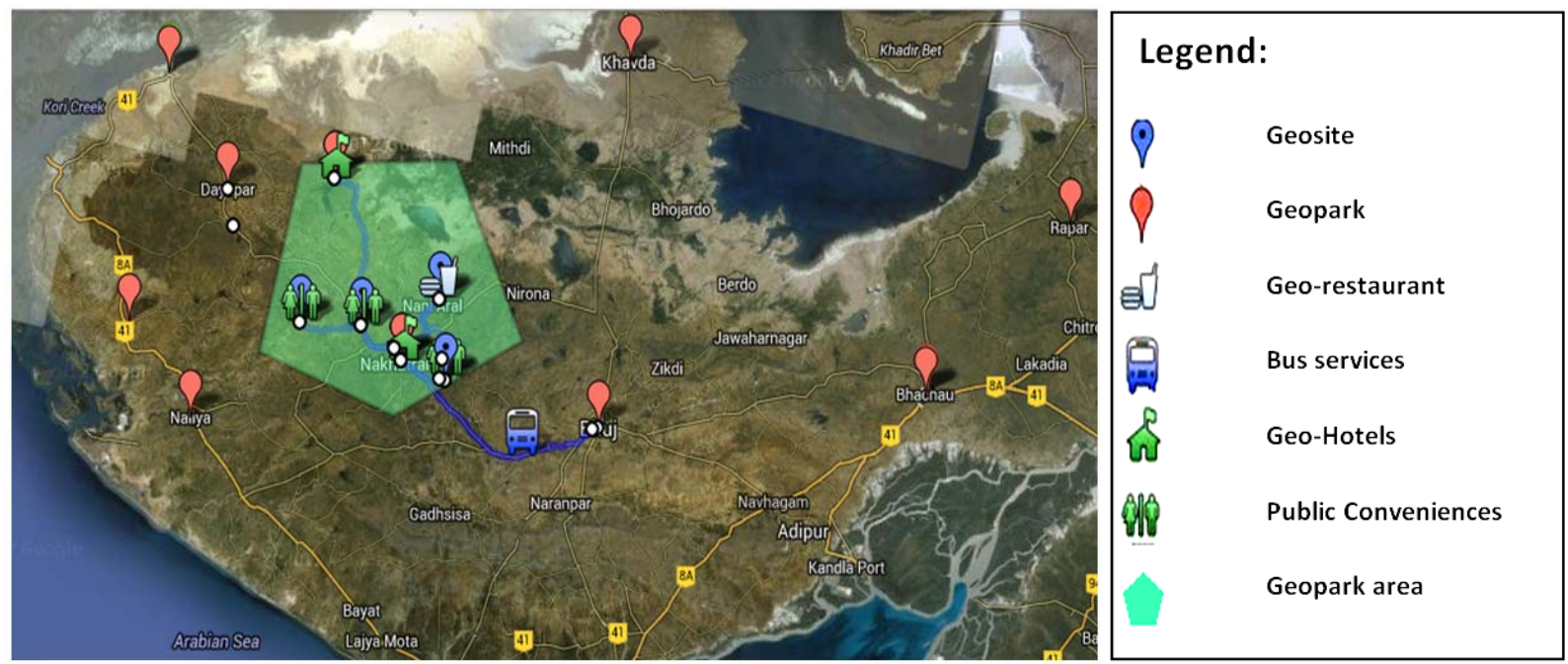

Figure 13. Route map for Nakhatrana geo-station-heading from Bhuj headquarter to Nakhatrana station by bus services, then to Vithonia hills, Dhinodhar hills, Netra and Mathal-Nara road section thus reaching the Nara geo-station with geohotels located at Nara and Nakhatrana, geo-restaurant at Dhinodhar site and public conveniences at each geosite. Red locations marked are geopark stations (from east to west)—Rapar, Bhachau, Khavda, Bhuj, Nakhatrana, Nara, Dayapar, Naliya, Lakhpat and Waior [31].

Bhuj. Kutch is certainly in a stage to showcase its geosites for active geotourism presenting its culture as well to the tourists and promoting its local economy.

\section{Acknowledgements}

First author is sincerely thankful to the Director of Gujarat Energy and Research Management Institute (GERMI) for his support and guidance throughout the completion of the manuscript and to the staff of GERMI who had guided end to end. Authors are grateful to Dr. Bhawanisingh Desai for sharing the field photos (shown in Figures 6, 8, 9 and 10) and also his help and contribution in collection of part of the data. Authors duly acknowledge the help and support given by Sri Srikarni, Director, GSI, Gandhinagar.

\section{REFERENCES}

[1] Wikipedia. http://en.wikipedia.org/wiki/Geotourism

[2] Global Geotourism Blogspot.

http://global-geotourism.blogspot.in/2011/09/father-of-m odern-geotourism.html

[3] National Geographic.

http://travel.nationalgeographic.com/travel/sustainable/ab out_geotourism.html

[4] S. K. Biswas, "The Miliolite Rocks of Kutch and Kathiawar (Western India),” Sedimentary Geology, Vol. 5, No. 2, 1971, pp. 147-164. http://dx.doi.org/10.1016/0037-0738(71)90029-7

[5] G. Sen, M. Bizimis, R. Das, D. K. Paul, A. Ray and S. K. Biswas, "Deccan Plume, Lithosphere Rifting, and Volcanism in Kutch, India,” Earth and Planetary Science Letters, Vol. 277, No. 1-2, 2009, pp. 101-111.

\section{http://dx.doi.org/10.1016/j.epsl.2008.10.002}

[6] S. K. Biswas and S. V. Deshpande, "The Basement of the Mesozoic Sediments of Kutch, Western India,” Bulletin of Geology, Mining \& Metallurgical Society of India, Vol. 40, 1968, pp. 1-7.

[7] S. K. Biswas, "Structure of Kutch-Kathiawar Region, Western India," Proceedings of the 3rd Indian Geological Congress, Pune, 1980, pp. 255-272.

[8] S. K. Biswas, "A Review of Structure and Tectonics of Kutch Basin, Western India, with Special Reference to Earthquakes,” Current Science, Vol. 88, No. 10, 2005, pp. 1592-1600.

[9] S. B. Shukla, "Late Quaternary Morphodynamic Evolution of the Northern Coast of Gulf of Kachchh Gujarat Western India,” Thesis, Maharaja Sayajirao University of Baroda, 2011. http://hdl.handle.net/10603/7485

[10] Dinosaur Fossil Image, Web, 2013. http://newscenter.berkeley.edu/2011/02/22/t-rex-more-hy ena-than-lion

[11] Directorate General of Hydrocarbons. http://www.dghindia.org/17.aspx

[12] Google Earth pro v7.0 2013. Kala Dunger, Kutch $23^{\circ} 55^{\prime} 59.59 " \mathrm{~N}, 69^{\circ} 48^{\prime} 49.33^{\prime \prime E}$, Elevation 406 Meters, 3D Buildings Data Layer.

[13] Dhinodhar Hill Rocks Image, WEB, 2013. http://mw2.google.com/mw-panoramio/photos/medium/1 904532.jpg

[14] Google Earth pro v7.0 2012. Jumara, Kutch $23^{\circ} 41.735^{\prime} N$, $69^{\circ} 4.186$ 'E, ele 15m, 3D Buildings Data Layer.

[15] A. Talib and K. N. Gaur, "Affinities and Palaeobiogeographic Implications of Middle to Late Jurassic Foraminifera from Jumara Hill, Kutch, India,” Neues Jahrbuch für Geologie und Paläontologie Abhandlungen, Vol. 247, No. 3, 2008, pp. 313-323. 
[16] Google Earth pro v7.0 2013. Jara, Kutch $23^{\circ} 42.904^{\prime} \mathrm{N}$, 68 58.384'E, ele 58m, 3D Buildings Data Layer.

[17] B. G. Desai and S. J. Patel, "Upper Callovian-Middle Oxfordian Belemnite Assemblage from Jara Dome, Western Kachchh,” Journal Geological Society of India, Vol. 74, No. 3, 2009, pp. 343-356.

http://dx.doi.org/10.1007/s12594-009-0135-4

[18] Google Earth pro v7.0 2011. Ukra, Kutch $23^{\circ} 45.510^{\prime} \mathrm{N}$, $68^{\circ} 51.440 ' E$, ele 83m, 3D Buildings Data Layer.

[19] National Working Group of Geological Survey of India, "Palaeoclimate in Asia during the Cretaceous-Their Variations, Causes and Biotic and Environmental Responses," Geological Survey of India, Kolkata, 2006. http://www.portal.gsi.gov.in/gsiDoc/pub/cs_24_palaeocli mate_gujarat.pdf

[20] B. K. Samanta, "Middle Eocene Planktonic Foraminifera from Lakhpat, Cutch, Western India,” The Micropaleontology Project, Inc., New York, 1970. http://dx.doi.org/10.2307/1485114

[21] J. Rai, V. P. Mishra, A. Sahni, A. Singh and F. J. Vega, "On Some Paleogene and Neogene Crabs of Kachchh, Western India,” Bulletin of the Mizunami Fossil Museum, Vol. 39, 2013, pp. 39-45.

http://www.city.mizunami.gifu.jp/odocs/sightseeing/fossil _museum/pdf/bulletin_39/bull39_03.pdf

[22] M. A. Sonar and S. G. Gaikwad, "Fossil Steginoporellid (Cheilostomata: Neocheilostomina), Bryozoa from the Tertiary Sediments of Western Kachchh, Gujarat, India,” Journal of Earth System Science, Vol. 122, No. 1, 2013, pp. 149-161.

[23] Limestone Formations Image, Web, 2013. http://img.geocaching.com/cache/large/31f69c05-3a75-44 ea-a69d-0e3392c7939c.jpg

[24] Lakhpat limestone Image, Web, 2013. http://www.indianaturewatch.net/displayimage.php?id=53 006

[25] S. K. Biswas, “Tertiary Stratigraphy of Kutch,” Journal of the Paleontological Society of India, Vol. 37, 1992, pp. $1-29$.

http://www.palaeontologicalsociety.in/vol37/v1.pdf

[26] D. K. Pandey and F. T. Fürsich, "Distribution and Succession of Jurassic Rocks in Gora Dongar, Pachchham 'Island', Kachchh, India," Journal Geological Society of India, Vol. 51, 1998, pp. 331-344. http://rogov.zwz.ru/Pandey,Fuersich,1998.pdf

[27] N. T. Farsani, C. Coelho, C. Costa and C. N. Carvalho, "Geoparks \& Geotourism: New Approaches to Sustainability for the 21st Century,” Brown Walker Press, Florida, 2011.

[28] Ministry of Tourism, GoI, "India Tourism Statistics at a Glance,” 2011.

http://tourism.gov.in/writereaddata/CMSPagePicture/file/mar ketresearch/INDIATOURISMSTATICS(ENGLISH).pdf

[29] Gujarat CM Website. http://www.narendramodi.in/those-who-know-the-touris m-sector-know-what-potential-there-is-gujarat-cm-at-guja rat-travel-mart

[30] Ministry of Tourism, GoI, “12th Five Year Plan,” 2012. http://planningcommission.nic.in/aboutus/committee/wrk grp12/wgrep_tourism.pdf

[31] “Kutch, Gujarat” Map. Google Maps, Web, 2013. 